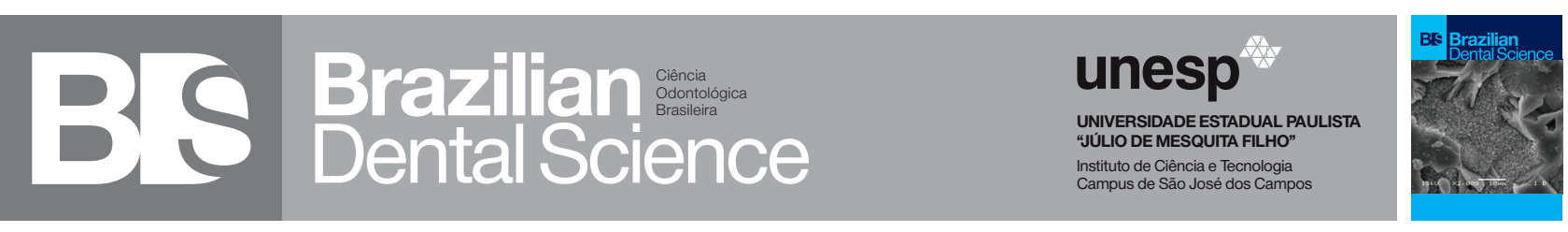

\title{
Correlation between bizygomatic and maxillary central incisor width for gender identification
}

\author{
Correlação entre a distância bizigomática e a espessura de incisivo central maxilar para identificação de gênero \\ Tasleem ABITHA ${ }^{1}$, Archana SANTHANAM ${ }^{1}$ \\ 1 - Saveetha Dental College - Saveetha Institute Of Medical and Technical Science - Saveetha University - Chennai - India.
}

\begin{abstract}
Objective: The aim of the present study is to analyze and evaluate the applicability of bizygomatic and maxillary central incisor width in identifying the sex of an individual for anthropological studies. Material and Methods: The study was conducted on 100 individuals in a private dental institution. The width of the central incisor was measured by requesting the subject to bite onto a sheet of modelling wax. The bizygomatic width was calculated with the help of a divider by taking the most prominent area of the zygomatic arch as the reference point bilaterally. Berry's formula was used to calculate the width of the maxillary central incisor from the bizygomatic width. Berry's Formula "Width of the maxillary central incisor $=$ Bizygomatic width / 16." The data obtained was tabulated and analyzed statistically. Results: The results in our study indicated that the widths of both maxillary central incisors and the bizygomatic width were found to be higher in males when compared to females with a positive strong correlation. Conclusion: The Berry's index can be used for identifying the gender and can also be used for facial reconstruction.
\end{abstract}

\section{KEYWORDS}

Berry's index; Bite mark; Bizygomatic width; Central Incisor; Gender identification.

\section{RESUMO}

Objetivo: O objetivo do presente estudo é analisar e avaliar a aplicabilidade da distância bizigomática e espessura de incisivos centrais maxilares na identificação do sexo de um indivíduo para estudos antropológicos. Material e métodos: O estudo foi conduzido com 100 indivíduos de uma instituição odontológica privada. A espessura do incisivo central foi medida pedindo ao sujeito que mordesse em uma folha de cera. A espessura bizigomática foi calculada com o auxílio de uma régua pegando a área mais proeminente do arco zigomático como ponto de referência bilateralmente. A fórmula de Berry foi usada para calcular a espessura do incisivo central maxilar da espessura zigomática. Fórmula de Berry: "Espessura do incisivo central maxial = Espessura bizigomática / 16". Os dados obtidos foram tabulados e analisados estatisticamente. Resultados: Os resultados em nosso estudo indicaram que as espessuras de ambos os incisivos centrais maxilares como as espessuras bizigomáticas foram maiores no sexo masculino do que no sexo feminino, com uma correlação positiva forte. Conclusão: $O$ índice de Berry pode ser usado para identificação de gênero e também pode ser usado para reconstrução facial.

\section{PALAVRAS-CHAVE}

Índice de Berry; Marca de mordida; Espessura bizigomática; Incisivo central; Identificação de gênero. 


\section{INTRODUCTION}

"R

ather than the functions in mastication and esthetics, tooth is a weapon secretly." Forensic odontology is the application of dental sciences for law and criminal investigations. Forensic dentistry is unique because each case is completely different \& even the seemingly routine case may take a look at the dentist's ingenuity in applying his dental information [1]. Basically, the theory behind forensic odontology is that, no two mouths are the same, even for identical twins [2]. The individuality of the human dentition assists in cases of victim identification [3]. The tragic incident involving the Twin Towers of the World Trade Centre in New York City, where mass graves were created, several victims remains were not identifiable without the use of dental forensics thus, delivering peace of minds to the families of the victims [4]. The most debatable and intricate areas of forensic odontology involves the analysis of bite marks.

Bite marks could be outlined as having occurred as a result of either a physical alteration in a medium caused by the contact of teeth or a representative mark left in an object or tissue by the dental structures of an animal or human [2]. The first bite mark case to be reported as an American judicial opinion was the 1954 Texas case of Doyle v. State. This case involved bite marks left in cheese at crime scene. The defendant, Doyle, was asked to bite an another piece of cheese and a comparison was made. The evidence was considered admissible and in fact it was the court's opinion that it was almost as convincing as finger print evidence [5].

Like fingerprints and DNA, bite marks are also distinctive to an individual. The primary step in analyzing the bite is to spot it as human because animal teeth are completely different from humans. The forensic odontologist should verify whether the bite was self-inflicted, as it can lead to false convictions. Human bite marks pose a great challenge to the forensic team due to their distortions caused by the elastic properties of the skin [6]. Maxillary and mandibular bite patterns also are dissimilar from one another and also differs in male and females. Thus, other alternates for identifying the deceased needs to be evaluated so that it can be presented to the court of law as a concrete proof against the suspect. Hence, the study was conducted to determine the correlation between the bizygomatic and maxillary central incisor width for both male and females as an adjuvant to aid in bite mark analysis.

For achieving maximum aesthetics during the setting of anterior teeth, selection of appropriate tooth size, form and width is essential. The proportion of facial structures and the relationship between facial measurements and natural teeth is used as a guide in selecting denture teeth. In the field of prosthodontics, Berry's biometric index is used for selection of anterior teeth [7].

Berry's Formula

"Width of the maxillary central incisor = Bizygomatic width / 16."

The bizygomatic width is an important measurement in craniometry and in forensic facial reconstruction for determining facial width [8]. The results inferred from the berry's index can be used for identifying the gender of a suspect.

\section{MATERIAL AND METHODS}

\section{Sample design:}

The present study was conducted in a private dental institution in Chennai with approval from the Institutional Review Board 
(SRB/SDBDS/SECOND/18-19/0120). The study group was comprised of 100 individuals which included 50 males and 50 females between the age of 18 to 40 years and an informed consent was obtained from each.

\section{Inclusion criteria:}

1) Complete set of permanent dentitions.

2) Absence of gingival or periodontal pathology

3) Absence of anterior restoration

4) No interdental spacing or crowding

5) No history of orthodontic treatment

\section{Study design:}

Each participant was seated in a dental chair in an upright position supported by the headrest, in a face forward position. The horizontal and occlusal plane of maxillary teeth were maintained parallel to the floor.

\section{Measurement of width of maxillary central incisor:}

The width of the right maxillary central incisor was measured by requesting the subject to bite onto a folded modelling wax sheet. The maximum width of the incisor was established by measuring the distance between the most distal point to the most mesial surface on the bite mark of the maxillary right central incisor on the modelling wax.

\section{Measurement of bizygomatic width:}

The bizygomatic width of each subject was calculated with the help of a divider (in millimeter) by taking the most prominent area of the zygomatic arch as the reference point bilaterally.

\section{Statistical analysis:}

The data obtained in the study were collected, tabulated and analyzed using the Statistical Package for Social Sciences, Version
19 (SPSS). Based on the values obtained, descriptive statistics were calculated using Students unpaired $\mathrm{T}$ test with the $\mathrm{p}=0.05$ or less considered as statistically significant. To measure the strength of correlation between the bizygomatic width and the width of the maxillary central incisor, the Pearson's $r$ and regression analysis was done. Garn and Lewis's formula was followed to calculate sexual dimorphism [9].

$$
([\mathrm{Xm} / \mathrm{Xf}]-1 \times 100)
$$
males.

$\mathrm{X}_{\mathrm{m}}=$ mean value of measurement for

$\mathrm{X}_{\mathrm{f}}=$ mean value of measurement for females.

\section{Results}

Table 1 depicts the descriptive statistics for the width of the upper central incisors and bizygomatic width for both male and female patients. The mean value of the width of the upper central incisor for males and females was $6.64 \mathrm{~mm}$ and $6.48 \mathrm{~mm}$, respectively. The mean value of the bizygomatic width for males and females was $106.30 \mathrm{~mm}$ and $103.70 \mathrm{~mm}$, respectively. The Student t-test revealed a statistically significant difference between males and females for the width of the upper central incisors and the bizygomatic width ( $\mathrm{p}=0.01)$ (Graph 1). The result showed a good strong positive correlation between the upper central incisor and the bizygomatic widths in both male and female patients $(r=1)$. (Table 2) (Graph 2 and 3). Overall correlation coefficient between the upper central incisor and the bizygomatic widths in the study population also showed strong positive correlation (Table 3 and Graph 4). Sexual dimorphism was higher for bizygomatic width when compared to upper central incisor width (Graph 5). 
Table 1 - Descriptive statistics for the width of the upper central incisor and bizygomatic widths

\begin{tabular}{|c|c|c|c|c|c|}
\hline \multicolumn{6}{|c|}{ Descriptive statistics for dental and facial measurement between gender } \\
\hline Gender & $\mathbf{N}$ & Standard deviation & Mean & $\begin{array}{c}\text { Standard error of } \\
\text { mean }\end{array}$ & P Value \\
\hline \multicolumn{6}{|c|}{ Width of maxillary central incisor } \\
\hline Male & 50 & 0.35 & 6.64 & 0.05 & \multirow{2}{*}{0.01} \\
\hline Female & 50 & 0.32 & 6.48 & 0.05 & \\
\hline \multicolumn{6}{|c|}{ Width of maxillary central incisor } \\
\hline Male & 50 & 5.53 & 106.30 & 0.78 & \multirow{2}{*}{0.01} \\
\hline Female & 50 & 5.20 & 103.70 & 0.73 & \\
\hline
\end{tabular}

Table 2 - Pearson's correlation coefficient $(r)$ between the upper central incisor and bizygomatic widths in males and females

\begin{tabular}{cccc} 
Width of upper central incisor & & Bizygomatic width & R square \\
\hline Sex & Standard error & $\mathbf{R}$ & 1 \\
\hline Female & $1.81 \mathrm{E}-18$ & 1 & 1 \\
\hline Male & $1.73 \mathrm{E}-18$ & 1 & 1
\end{tabular}

Table 3 - Overall correlation coefficient ( $r$ ) between the upper incisal and bizygomatic widths in study population

\begin{tabular}{|c|c|}
\hline Overall correlation & Bizygomatic width \\
\hline \multicolumn{2}{|c|}{ Bizygomatic width } \\
\hline \multicolumn{2}{|c|}{ Width of maxillary central incisor } \\
\hline $\mathbf{R}$ & 1 \\
\hline R Square & 1 \\
\hline Standard error of mean & 0.49060459 \\
\hline
\end{tabular}




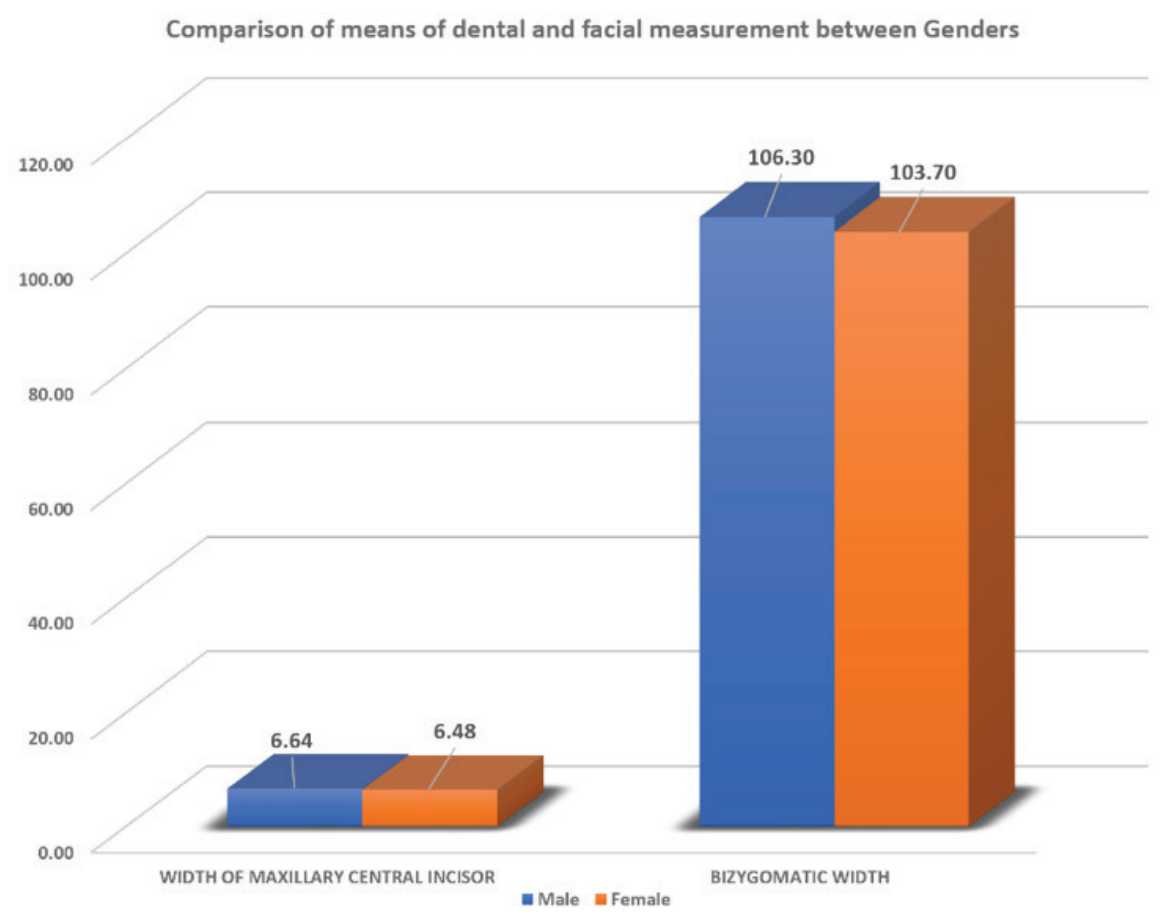

Graph 1- Graphical representation of means of the upper central incisor and bizygomatic widths in study population.

\section{BIZYGOMATIC WIDTH (in mm) MALES}

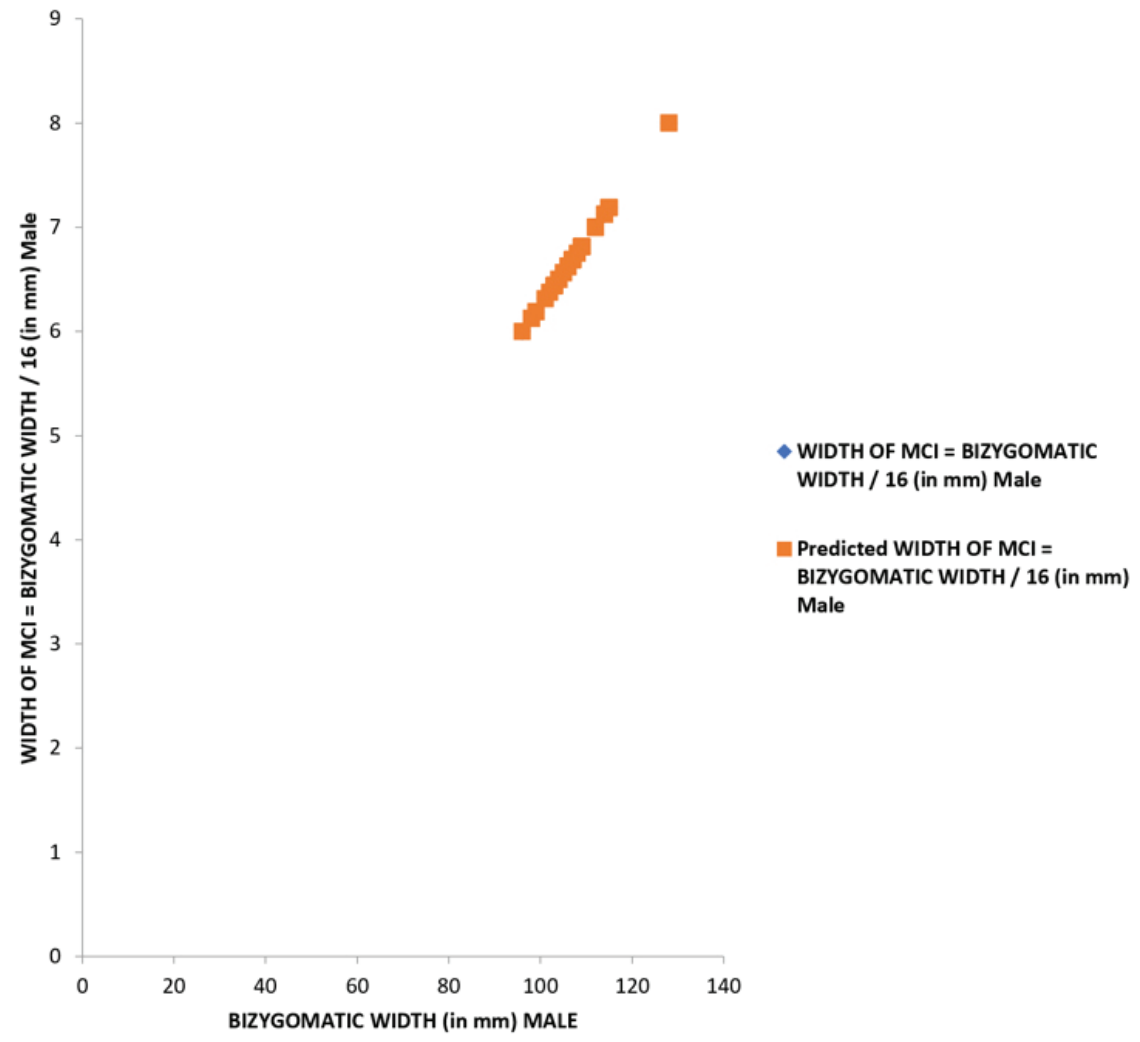

Graph 2 - Graphical representation of correlation between the upper incisal and bizygomatic widths in males. 


\section{BIZYGOMATIC WIDTH (in mm) FEMALES}

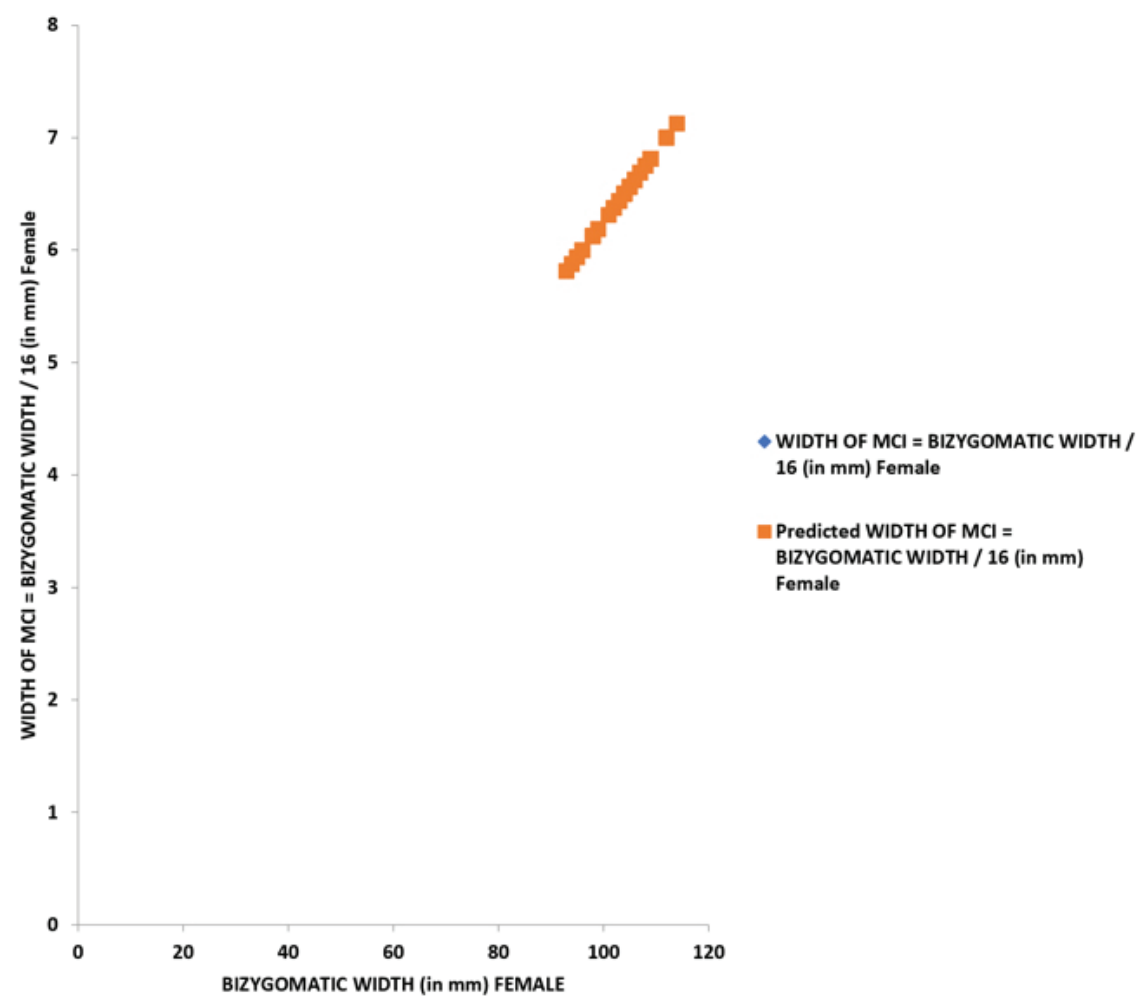

Graph 3 - Graphical representation of correlation between the upper incisal and bizygomatic widths in females.

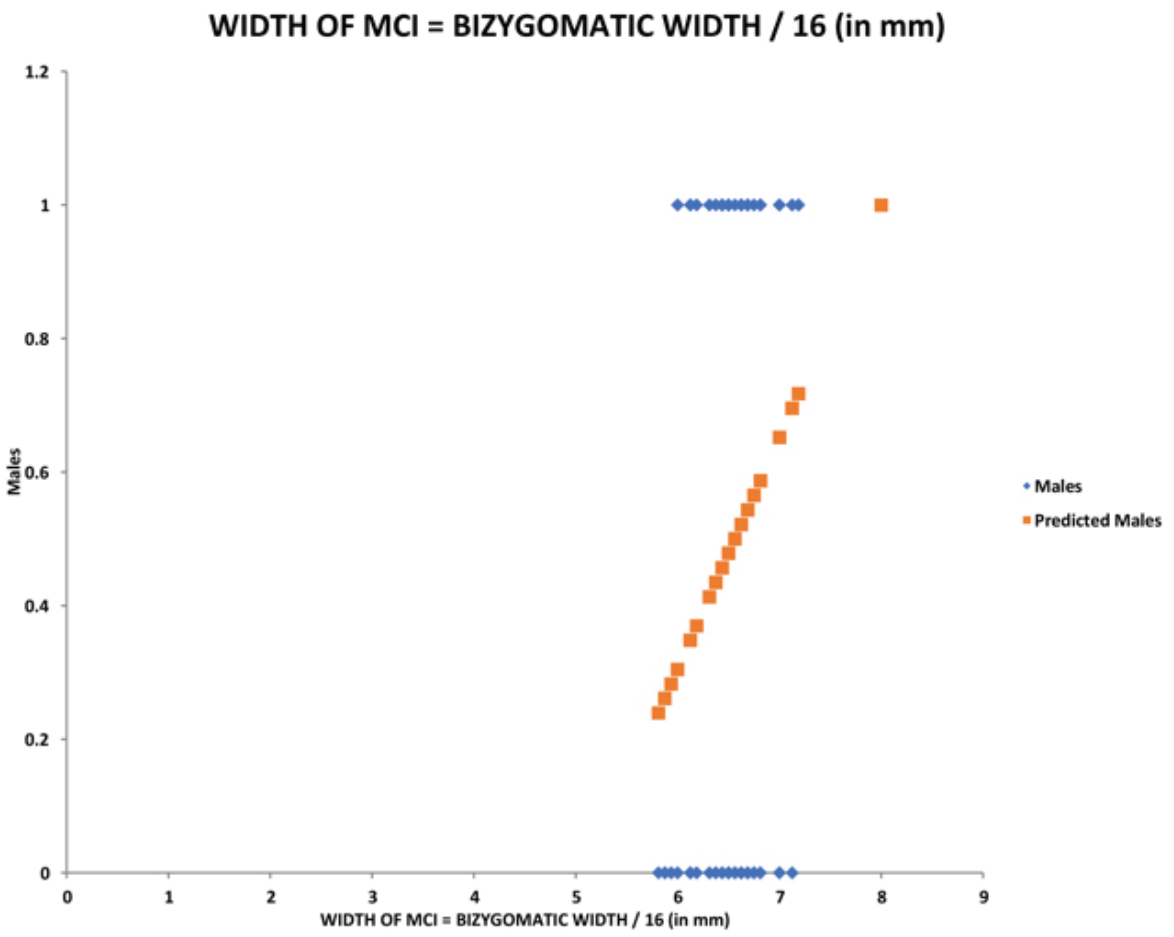

Graph 4 - Graphical representation of correlation between the upper incisal and bizygomatic widths in study population. 


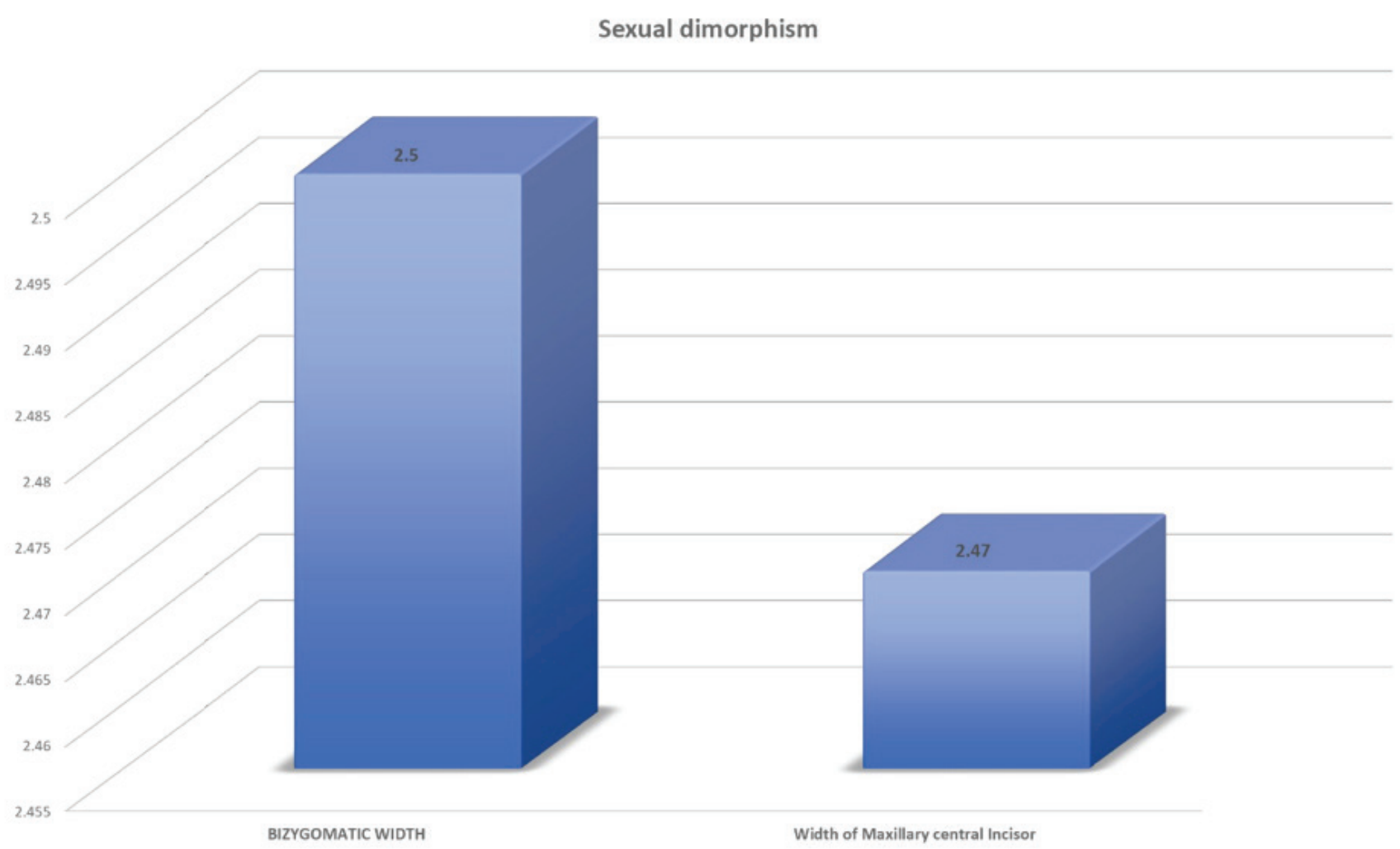

Graph 5 - Graphical representation of sexual dimorphism between the upper incisal and bizygomatic widths in study population.

\section{DISCUSSION}

In today's world, we human beings are eager to know more about world events, where crime rates have tremendously increased and most crimes are unrevealed due to lack of evidence. In such situations, identification of the victim relies on the role played by forensic odontologists in identifying and solving the crime. The individuality of the human dentition allows reaching a strong opinion in cases of victim identification [3]. Bite marks on human tissues can be observed in violent incidents such as sex-related crimes, child abuse cases, and offenses involving physical altercations, such as homicide [10]. Two main streams of forensic significance of bite marks are its anatomical location and severity of the injury. An array of controversies exists regarding bite mark evidence such as errors in recording, comparison, analysis and its interpretation [11]. Human bite marks pose a greatest challenge to the forensic team due to its distortion caused by the elastic properties of the skin [6].

Berry postulated a direct relationship between the dimensions of the upper central incisor with facial dimensions [7]. This indexing in the field of prosthodontics has been used for selection of anterior teeth based on the facial proportion, one such being the bizygomatic width. Dimensions of the bizygomatic width plays an important role in facial reconstruction where the body is completely mutilated beyond identification. Hence, the present study aims to determine the correlation between the bizygomatic and maxillary central incisor widths for both males and females as an adjuvant to aid in bite mark analyses.

From the current study, we found that both the maxillary central incisor and bizygomatic widths are greater in males compared to females, which is in accordance with the previous studies conducted by Gillen 
et al., Sterrett et al., Owens et al., [12-14] But in a study conducted by Sinthia Bhagat et al., the mean values of the maxillary central incisor and bizygomatic widths were greater in females compared to males, which is in contrast to the results of the present study [15]. The results also showed a strong positive correlation between the bizygomatic and maxillary central incisor widths, in both males and females, which is in accordance with the previously published results of Sinthia Bhagat et al., Palathottungal et al., $[15,16]$ These results can further be used in gender identification through facial features at the crime scene. For both facial and dental measurements, sexual dimorphism was greater in males compared to females. It could be due to the fact that men have larger teeth and faces than women, although sex has little influence on tooth-to-face proportions [17].

Limitation of the present study is that these results are region specific and there are morphological variations depending upon the geographical conditions. Considering diverse geographical conditions of the country, it is proposed that similar studies should be carried out on varied subjects of different regions in the direction of improving accuracy of using linear dimensions of teeth as a method of sex determination.

Table 4 - Comparison of dental and facial measurements with previous studies

\begin{tabular}{|ccc|c|}
\hline Parameters & $\begin{array}{c}\text { Palathottungal } \\
\text { et al.,2015 }\end{array}$ & $\begin{array}{c}\text { Sinthia } \\
\text { bhagat et } \\
\text { al.,2018 }\end{array}$ & $\begin{array}{c}\text { Tasleem et } \\
\text { al., 2019 }\end{array}$ \\
\hline $\begin{array}{c}\text { Width of maxillary } \\
\text { central incisor } \\
\text { female }\end{array}$ & 7.765 & 8.13 & 6.48 \\
\hline $\begin{array}{c}\text { Width of maxillary } \\
\text { central incisor male }\end{array}$ & 7.602 & 8.03 & 6.64 \\
\hline $\begin{array}{c}\text { Bizygomatic width } \\
\text { female }\end{array}$ & 124.2 & 112.48 & 103.7 \\
\hline $\begin{array}{c}\text { Bizygomatic width } \\
\text { male }\end{array}$ & 125.4 & 111.2 & 106.3 \\
\hline $\begin{array}{c}\text { Pearson's corre- } \\
\text { lation }\end{array}$ & 0.628 & 0.613 & 1 \\
\hline
\end{tabular}

\section{CONCLUSION}

The incisal width obtained from a bite mark can possibly form an impression regarding the facial width of the individual. Hence, from the current study it is evident that there is a strong positive correlation between the bizygomatic and maxillary central incisor widths. The Berry's index can be used as a valuable tool for determining the gender, in identifying the victims, as well as in facial reconstruction.

\section{REFERENCES}

1. Dinakaran J, Dineshkumar T, Nandhini G, Priyadharshini N, Rajkumar K. Gender determination using dentition. SRM J Res Dent Sci. 2015;6(1):29-34. doi: 10.4103/0976-433X.149587.

2. Kennedy D. Forensic dentistry and microbial analysis of bite marks. J Forensic Sci. 2011:6-15. [Internet] Avaiable at:https://pdfs.semanticscholar.org/28d3/6 deff2a9f9fb000da2b8024881898a5bf026.pdf

3. Acharya AB, SivapathasundharamB. Forensic odontology. In: Rajendran $R$, Sivapathasundharam B, editors. Shafer's Textbook of Oral Pathology. 5 ed. NewDelhi:Elsevier;2006.p1199-1227.

4. Thomas W. Eagar, Christopher Musso. Why Did the World Trade Center Collapse? Science, Engineering, and Speculation. JOM. 2001;53(12):8-11.

5. Forensic Dental Services. Doyle v. State: 159 Tex Crim. 310,263 S.W.2d 779. [Internet] Avaiable at:http://www.forensicdentalservices.co.uk/?p0574

6. Rothwell BR. Bite marks in forensic dentistry: A review of legal, scientific issues. J Am Dent Assoc. 1995Feb;126(2):223-32.

7. Bhagat S, Gupta V, Tyagi N, SharmaE, GuptaS, Dadu M. Berry's index: Adjuvant to bite marks. J Forensic Dent Sci. 2018 Jan-Apr;10(1):45-9. doi:10.4103/jfo. jfds_99_16.

8. Van der Velden A, Spiessens M, Wilems G. Bite mark analysis and comparison using image perception technology. J Forensic Odontostomatol. 2006 Jun;24(1):14-7.

9. Garn SM, Lewis AB, Kerewsky RS. The relationship between sexual dimorphism in tooth size and body size as studied within families. Arch Oral Biol. 1967 Feb;12(2):299-301.

10. Giannelli PC. Bite Mark Analysis. Paper 153. Faculty Publications. 2007. Avaiable at:https://scholarlycommons.law.case.edu/faculty_publications/153

11. Bhargava K, Bhargava D, Rastogi P,Paul M, Paul R, Jagadeesh HG, etal. An overview of bite mark analysis. J Indian Acad Forensic Med. 2012 JanMar;34(1):61-6.

12. Gillen RJ, SchwartzRS, Hilton TJ, Evans DB. An analysis of selected normative tooth proportions. Int JProsthodont. 1994 Sep-0ct;7(5):410-7.

13. Sterrett JD, Oliver T, Robinson F, Fortson W, Knaak B, Russell CM. Width/ length ratios of normal clinical crowns of the maxillary anterior dentition in man. JClin Periodontol. 1999 Mar;26(3):153-7. 
14. Owens EG, Goodacre CJ, Loh PL, Hanke G, Okamura M, Jo KH, etal. A multicenter interracial study of facial appearance. Part2: A comparison of intraoral parameters. Int J Prosthodont. 2002 May-Jun;15(3):283-8.

15. Bhagat S, Gupta V, Tyagi N, SharmaE, Gupta S, Dadu M. Berry's index: Adjuvant to bite marks. JForensic Dent Sci.2018 Jan-Apr;10(1):45-49. doi:10.4103/jfo. jfds_99_16.
16. Antony PJ,Pillai KS, George GB, Varghese T,Puthalath MS, Arakkal LJ, et al. Applicability of berry's index in bite mark analysis. J Forensic Dent Sci. 2015 Jan-Apr;7(1):28-31. doi: 10.4103/0975-1475.150299.

17. 17. Kurt A, Isik-0zkol G. Conventional methods for selecting form, size, and color of maxillary anterior teeth: Review of the literature. Eur J Prosthodont. 2015;3(3):57-63. doi: 10.4103/2347-4610.166184

\section{Dr. Archana Santhanam}

(Corresponding address)

162, Poonamallee High Road, Chennai-600077,

Tamil Nadu, India.

Date submitted: 2019 Apr 11

Email: drarch.s@gmail.com 